\title{
MEMBANGUN MASYARAKAT BERPENGHARAPAN: BELAJAR DARI PENGALAMAN WARGA DUSUN CABEN KABUPATEN BANTUL
}

\author{
Yoachim Agus Tridiatno \\ Universitas Atma Jaya Yogyakarta \\ Email: tridiatno@yahoo.com \\ Chatarina Suryanti \\ Universitas Atma Jaya Yogyakarta \\ Email: chsuryanti@yahoo.com
}

\begin{abstract}
This paper describes how the people of Caben, Bantul, Yogyakarta, were able to carry out the crisis of earthquake on May 27, 2006. It happened because of their hopes and submission to God. These attitudes have been refined through spreading love and solidarity between people. This research found that love and solidarity cannot be separated from the virtue of hope and faith. These two essential virtues are very important for those who suffer from a disaster. Learning from the people of Caben, Bantul, this paper considers that a hopeful community could be constructed by spreading love and solidary. Social encounters and cooperation must be continuously preserved to make social cohesion and network. It represents a thankful behavior toward the mercy of God. It is always relevant to have such a hopeful community here in Indonesia as the country of disaster.
\end{abstract}

[Makalah ini menjelaskan bahwa penduduk Dusun Caben, Kabupaten Bantul, mampu bangkit dari 
keterpurukan akibat gempa bumi, 27 Mei 2006. Hal itu disebabkan mereka memiliki pengharapan sekaligus kepasrahan kepada Tuhan. Sikap berpengharapan dan pasrah kepada Tuhan tersebut tumbuh dan berkembang karena cinta dan solidaritas dari sesama manusia. Penelitian ini menunjukkan bahwa keutamaan cinta dan solidaritas tidak bisa dipisahkan dari keutamaan harapan dan iman. Keutamaan harapan dan iman merupakan keutamaan yang sangat penting bagi mereka yang menderita akibat bencana. Belajar dari pengalaman penduduk Caben, Bantul, artikel ini menegaskan bahwa masyarakat yang berpengharapan dapat dibangun dengan cara mengembangkan semangat cinta dan solidaritas. Perjumpaan atau kerjasama harus secara berkala ditumbuhkembangkan guna melatih masyarakat untuk memiliki sikap solider, setia kawan, dan sikap bersyukur atas segala bantuan sebagai anugerah Tuhan. Masyarakat berpengharapan sangat penting keberadaannya bagi Indonesia sebagai negeri seringkali ditimpa bencana.]

Keywords: hope, faith, love, and solidarity.

\section{Pendahuluan}

Banyak pihak kagum dan mengapresiasi penanganan bencana gempa bumi yang terjadi di Yogyakarta pada 27 Mei 2006. Hadirnya solidaritas kemanusiaan yang kokoh di tengah modernisme yang cenderung individualis dan egois menjadi bukti. Pelbagai bantuan mengalir dari segala penjuru, mulai dari bantuan darurat hingga bantuan pemulihan (recovery). Pertanyaannya, dari mana solidaritas itu muncul? Apakah semata kesadaran kemanusian atau ia berakar dari solidaritas Tuhan kepada ciptaanNya. ${ }^{1}$ Mungkin, solidaritas itulah yang menyebabkan korban bencana bisa segera bangkit dari keterpurukan, tapi tak seharusnya

${ }^{1}$ Albertus Kristiadji Rahardjo, Theology of Solidarity in Times of Disaster and Suffering. Theological Reflections Based on the Experiences of a Post-Disaster Christian Community in Kintelan, Bantul, Yogyakarta (Yogyakarta: Thesis S2 Center for Religious and Cross-Cultural Studies, 2007). 
refleksi ini terhenti pada solidaritas semata. Ada keutamaankeutamaan lain yang melandasi kasih kemanusian, yakni pengharapan dan iman. Penelitian ini bermaksud membuktikan bahwa solidaritas kemanusian tidak bisa dilepaskan dari pengharapan dan iman: membangun masyarakat yang berpengharapan dan beriman adalah penting.

Bantuan dan bentuk ungkapan simpatik dari sesama terhadap korban bencana sifatnya hanya sementara. Ungkapan bela sungkawa dan penghiburan biasanya hanya terjadi di saat-saat berduka, dan sesudahnya kehidupan kembali berjalan seperti biasa. Lalu tinggallah korban yang harus menghadapi kenyataan bencana itu sendiri. Oleh karena itu, kematangan dan kedewasaan pribadi dalam bentuk sikap berpengharapan dan beriman sangat menentukan bagaimana seseorang menyikapi bencana dan berusaha untuk bangkit dari keterpurukan. Refleksi atas pengalaman: bagaimana menyikapi bencana, khususnya yang dimanifestasikan dalam kata-kata bijak, sikap dan keutamaankeutamaan moral para korban akan sangat bermanfaat. Keberanian korban untuk pasrah, berserah diri, menerima kenyataan, sekaligus punya pengharapan untuk bangkit dari keterpurukan penting diteliti agar menjadi bahan pembinaan mental dan kepribadian bagi masyarakat, sehingga mereka siap menghadapi bencana terburuk sekalipun yang mungkin terjadi.

Masyarakat Jawa memandang nrima atau pasrah sebagai salah satu tanda kematangan moral di samping sabar dan ikhlas. ${ }^{2}$ Nrima berarti menerima apa saja yang mendatangi kita tanpa protes dan pemberontakan. Sikap nrima yang dimaksud di sini adalah sikap positif. Nrima berarti bahwa seseorang bisa bersikap rasional dan tidak ambruk, meski ia berada dalam keadaan kecewa dan kesulitan, serta tidak menentang secara percuma. Nrima menuntut kekuatan untuk menerima apa yang tidak dapat dielakkan tanpa membiarkan diri dihancurkan olehnya. Sikap nrima memberi daya tahan untuk juga menanggung nasib yang buruk. ${ }^{3}$ Di samping kata nrima ada juga kata sumeleh yang berarti pasrah dan menyerah. Sumeleh adalah tingkat kedewasaan moral tertinggi. Orang yang

\footnotetext{
${ }^{2}$ Franz Magnis Suseno, Etika Jawa Sebuah Analisa Falsafi tentang Kebijaksanaan Hidup Jawa (Jakarta: Gramedia, 1984), 142.

3 Ibid., 143.
} 
mampu sumeleh adalah orang yang matang dan dewasa, yang mampu melepaskan diri dari segala macam kepentingan. Sikap demikian dapat dicapai karena ia memiliki pengharapan akan keselamatan, sebab ia hanya serupa bagian kecil dari makrokosmos atau jagad gedhe. Artinya, di balik sikap nrima atau pasrah terdapat pengharapan yang kuat akan keselamatan yang datang dari pihak lain, entah dari sesama atau Tuhan. Sikap nrima dan pasrah dilandasi oleh adanya pengharapan. Pasrah dan berharap berkaitan sangat erat. Namun, pengharapan berperan penting karena mendasari sikap nrima itu.

Menurut Bernadus Wibowo Suliantoro yang melakukan penelitian tentang orientasi nilai budaya abdi dalem Kraton Yogyakarta, beberapa kearifan lokal masyarakat Jawa khususnya yang menjadi abdi dalam kraton Yogyakarta sangat kuat dipengaruhi oleh filosofi Jawa. ${ }^{4}$ Salah satunya adalah kearifan lokal "tepa selira" atau tenggang rasa. Prinsip ini merupakan keutamaan moral masyarakat Jawa. Prinsip tenggang rasa menuntut agar orang menjaga hubungan baik dengan sesama dengan cara mengasihi sesama terutama mereka yang sedang menderita. Prinsip tenggang rasa menuntut kepekaan sosial atas penderitaan hidup sesama dengan mengembangkan prinsip solidaritas. Wujud konkret dari pengembangan prinsip tersebut adalah memberikan bantuan apabila ada tetangga yang membutuhkan bantuan tenaga dalam bentuk sambatan atau kerja bakti. Di samping itu, terdapat pula keutamaan moral sabar, nrima, dan ikhlas.

Agama-agama, khususnya Kristen dan Islam, menyatakan bahwa pasrah adalah sikap iman yang mengandalkan sepenuhnya pada Tuhan. Sikap pasrah itu tumbuh dan berkembang, karena kepercayaan yang total kepada Tuhan. Sikap pasrah tersebut juga disertai harapan akan keselamatan yang akan diberikan oleh Tuhan. Dalam teologi moral Kristen, iman, harapan, dan kasih merupakan keutamaan teologal.

Dengan latar belakang tersebut, penelitian ini dibuat. Penelitian ini menggali pengalaman masyarakat dusun Caben,

\footnotetext{
${ }^{4}$ Bernadus Wibowo Suliantoro, Studi Tentang Orientasi Nilai Budaya Abdi Dalem Kraton Yogyakarta: Laporan Penelitian Mandiri (Yogyakarta: Universitas Atma Jaya Yogyakarta, 2001).
} 
Kabupaten Bantul, atas pengalaman gempa 27 Mei 2006, khususnya berkaitan dengan keutamaan pengharapan yang dapat menjadi penggerak untuk bangkit dari keterpurukan akibat gempa. Penelitian ini akan menemukan faktor-faktor yang menyebabkan masyarakat Dusun Caben tetap memiliki pengharapan di tengah musibah bencana gempa. Pengalaman masyarakat Dusun Caben, Kabupaten Bantul ini diharapkan bisa menjadi pelajaran bagi masyarakat Indonesia lainnya.

Indonesia, kita tahu, adalah negeri yang penuh dengan bencana. Setiap tahun pasti terjadi bencana-bencana besar: banjir, tanah longsor, gempa bumi, gunung meletus, dan kecelakaankecelakaan yang sering tidak terduga. Semuanya membutuhkan perhatian, penanganan, dan dana yang tidak kecil. Masyarakat Indonesia mesti disiapkan untuk menghadapi pelbagai bencana tersebut. Tidaklah cukup bila masyarakat hanya mengharapkan uluran bantuan dari pemerintah. Masyarakat sendiri harus tahan dan tangguh terhadap bencana. Masyarakat yang demikian adalah masyarakat yang berpengharapan karena beriman dan saling setia kawan kepada sesama mereka. Maka, membangun masyarakat yang selalu berpengharapan adalah penting. Bukan hanya bangunan rumah dan gedung yang harus tahan bencana, tetapi masyarakat pun harus dibangun agar tahan bencana. Inilah relevansi penelitian ini.

Penelitian ini dilakukan dua belas tahun setelah bencana gempa di Yogyakarta dan Jawa Tengah itu terjadi. Dengan jarak waktu yang cukup jauh dari peristiwa bencana itu, penelitian ini bukan lagi ingin menggali memori tentang peristiwa bencana itu, tetapi refleksi para penyintas (survivors) bencana itu tentang pengalaman mereka hingga dapat bangkit dari keterpurukan itu. Refleksi tersebut sudah lebih tertata, lebih jernih dan tidak emosional. Dengan refleksi itu, diharapkan masyarakat dapat melihat jauh ke dalam inti pengalaman pribadi, bukan lagi sekedar faktor-faktor luar yang mudah dilihat dan dirasakan.

Ada beberapa pertanyaan yang ingin dijawab oleh penelitian ini. Pertama, faktor apa yang membantu masyarakat Dusun Caben untuk bertahan (survive) dalam menghadapi musibah gempa? Keutamaan-keutamaan apa yang dimiliki oleh masyarakat Dusun Caben sehingga dapat bangkit dari keterpurukan akibat 
bencana besar tersebut? Kedua, bagaimana proses masyarakat dusun Caben bisa sampai pada sikap (disposisi) "berpengharapan" dalam menghadapi bencana itu? Ketiga, bagaimana masyarakat Dusun Caben mengembangkan sikap berpengharapan itu sehingga dapat mempercepat pemulihan dari keterpurukan akibat bencana? Keempat, apakah kendala-kendala yang merintangi para penyintas untuk sampai pada sikap berpengharapan?

\section{Gambaran Umum tentang Gempa Bumi 27 Mei 2006}

Gempa bumi 27 Mei 2006 terjadi di wilayah Propinsi Daerah Istimewa Yogyakarta dan Jawa Tengah pada pukul 05:52 waktu setempat atau 26 Mei 2006 pukul 22:54 GMT. Titik episentrumnya di Samudra India, kira-kira 33 kilometer sebelah selatan Kabupaten Bantul, Daerah Istimewa Yogyakarta. ${ }^{5}$ Dengan kekuatan 5.9 skala richter, gempa tersebut mengenai lima kabupaten di Daerah Istimewa Yogyakarta dan enam kabupaten di Jawa Tengah. Kabupaten Bantul merupakan wilayah yang terkena dampak berat dari gempa bumi itu di samping Kabupaten Klaten, Kulonprogo, Yogyakarta, Gunung Kidul, dan Sleman.

Kerugian akibat bencana diperkirakan mencapai Rp 29.1 trilyun (US\$ 3.1 milyar). Sektor-sektor privat, seperti rumah tangga, perusahaan-perusahaan swasta terkena dampak yang sangat berat. Ribuan rumah hancur rata dengan tanah dan ribuan orang kehilangan pekerjaan. Karena wilayah yang terdampak gempa adalah daerah-daerah yang padat penduduknya, maka jumlah korban jiwa sangat banyak. Diperkirakan 6200 orang meninggal. Sebagian besar korban adalah penduduk yang miskin.

Suasana di wilayah bencana menjadi sangat mengerikan, ketika terdengar isu-liar tentang akan terjadinya tsunami. Banyak orang yang sudah luka-luka atau patah tulang karena tertimpa reruntuhan bangunan harus melarikan diri dari daerah mereka untuk menghindari terjangan tsunami. Lalu lintas menjadi kacau balau dan macet. Ada cerita yang mengenaskan, bahwa seorang laki-laki yang sedang sakit parah terpaksa diikat di sebuah pohon

\footnotetext{
${ }^{5}$ Bappenas (2006) sebagaimana dikutip oleh Gunadi Brata, Aloysius et al., "The Impact of the 2006 Yogyakarta Earthquake on Local Economic Growth" in EconDisCliCha (2018) 2:203-224 (dapat diakses di https://doi.org/10.1007/s41885-018-0026-5).
} 
oleh keluarganya karena keluarga itu tidak mungkin membawa saudaranya yang sakit tersebut untuk melarikan diri. Harapannya adalah saudaranya yang sakit itu tidak akan terbawa oleh tsunami. Akhirnya, tsunami itu memang hanyalah isu dan tidak menjadi kenyataan. Meskipun demikian, isu tsunami dapat juga menjadi ujian bagi iman dan kepercayaan masyarakat. Banyak penyintas yang menyatakan bahwa mereka tidak takut akan datangnya tsunami dan mereka tetap tinggal di rumah karena mereka percaya sepenuhnya pada perlindungan Tuhan.

Bencana gempa bumi 2006 ini membutuhkan dana yang besar untuk rekonstruksi dan rehabilitasi. Namun, yang menarik adalah bahwa rekonstruksi atas bencana di Jawa berlangsung lebih cepat dibandingkan dengan rekonstruksi atas bencana di Aceh dan Nias. ${ }^{6}$ Asumsi umum menyatakan bahwa solidaritas masyarakat Jawa yang sangat kuat menjadi faktor penentu lancar dan cepatnya rekonstruksi atas bencana di Jawa, meskipun ada banyak faktor yang mempengaruhi lancar dan cepatnya rekonstruksi atas gempa di Yogyakarta dan Jawa Tengah ini tersebut. Faktor solidaritas inilah yang menjadi bahan refleksi utama sebagaimana dinyatakan di atas.

\section{Metode Penelitian}

Penelitian ini merupakan penelitian kualitatif deskriptif. Pengumpulan data penelitian lapangan dilakukan dengan cara mengeksplorasi pengetahuan, sikap, perilaku dan pandangan hidup masyarakat dalam memaknai terjadinya musibah akibat bencana alam. Hal ini dilakukan dengan keterlibatan langsung (partisipatif) peneliti dalam kehidupan masyarakat dusun Caben. Dalam keterlibatan itu dilakukan wawancara, dialog dalam sebuah forum group discussion (FGD) dan observasi hingga ditemukan data yang diperlukan.

Sumber data utama dalam penelitian lapangan adalah masyarakat dusun Caben yang menjadi responden. Responden untuk wawancara dan FGD bersifat terbatas dan terarah pada

\footnotetext{
${ }^{6}$ World Bank (2007) sebagaimana dikutip oleh Gunadi Brata, Aloysius et al., "The Impact of the 2006 Yogyakarta Earthquake on Local Economic Growth" in EconDisCliCha (2018) 2:203-224 (dapat diakses di https://doi.org/10.1007/s41885-018-0026-5).
} 
orang-orang tertentu, berdasarkan kriteria: korban yang rumahnya rata dengan tanah akibat gempa, dan yang kehilangan anggota keluarga (ada yang meninggal dunia). Hasil wawancara, dan FGD dengan warga dusun Caben menjadi data primer yang penting karena dari wawancara dan FGD ini dapat digali keutamaan, karakter, dan filosofi masyarakat dusun Caben. Di samping itu, penelitian kepustakaan dilakukan untuk mencermati buku-buku yang terkait dengan makna harapan, pasrah, dan penderitaan menghadapi bencana alam dalam kerangka pemikiran teologis, filosofis maupun kultural.

Dusun Caben, Sumbermulyo, terletak sekitar 8 kilometer dari Kota Bantul dengan luas tanah 64 hektar, yang terdiri dari 34 hektar tanah sawah dan 30 hektar tanah pekarangan, dan jumlah penduduk 1.177 orang yang dikelola oleh enam Rukun Tetangga (RT). Penduduk di dusun tersebut beragama Kristen Protestan, Katolik, Islam, dan Hindu, dengan rincian sebagai berikut: Islam sebanyak 661 orang, Katolik sebanyak 507 orang, Kristen Protestan sebanyak 5 orang, dan Hindu sebanyak 4 orang. Pada waktu gempa bumi 27 Mei 2006 terdapat 63 orang meninggal, di antara mereka 57 orang meninggal pada saat gempa. Sebagian besar rumah penduduk roboh rata dengan tanah. Dengan kondisi semacam itu, lokasi ini dipandang amat tepat untuk dijadikan lokasi penelitian ini.

Untuk mengumpulkan data, peneliti melakukan beberapa kali kunjungan ke lokasi untuk mengenali situasi masyarakat dusun Caben, Kabupaten Bantul. Peneliti mewawancarai 18 orang responden dan melakukan dua kali FGD dengan 13 orang. Ada tiga orang yang diwawancarai juga mengikuti FGD. Jadi keseluruhan responden ada 28 orang.

FGD pertama diikuti oleh responden yang beragama Katolik, sedangkan FGD kedua diikuti oleh responden yang beragama Islam. Pengelompokan responden FGD berdasarkan agama dimaksudkan untuk memberi keleluasaan pada responden untuk membagikan pengalaman mereka tanpa terhambat oleh perbedaan agama. Hal ini juga dimaksudkan untuk mengetahui bila agama menjadi variabel pembeda dalam penelitian ini. Dalam kenyataannya, tidak ada perbedaan dalam hal pengalaman iman 
menghadapi bencana dari responden yang beragama Katolik dan Islam.

Dilihat dari jenis kelamin para responden, terdapat 17 orang laki-laki dan 11 orang. Sebagian besar responden bekerja di sekitar dusun Caben sebagai petani dan peternak. Dua orang bekerja di Panti Asuhan Ganjuran, seorang menjadi sopir, dan seorang bekerja di kota Bantul. Semua responden menanggung kerugian materi akibat bencana gempa bumi Mei 2006. Sebagian besar rumah responden roboh dan rata dengan tanah. Hanya dua responden yang rumahnya tidak roboh karena dibangun sendiri dengan material yang berlebih sehingga bangunan sangat kuat. Memang, semua responden tidak menghitung secara persis berapa rupiah kerugian yang mereka derita.

Semua responden mengalami kehilangan sanak saudara dan tetangga dekat yang meninggal akibat gempa Mei 2006. Dari 63 orang korban jiwa di Caben, 17 orang yang meninggal adalah sanak saudara dan tetangga dekat dari responden. Gambaran ini ingin menunjukkan bahwa responden yang dipilih dalam penelitian ini benar-benar penyintas (survivors) yang sungguh memiliki pengalaman penderitaan mendalam akibat gempa. Pengalaman penderitaan ini diharapkan dapat menjadi bahan refleksi yang sesuai dengan diharapkan oleh penelitian ini.

\section{Harapan sebagai Keutamaan}

Harapan adalah sesuatu yang pokok bagi hidup manusia. Harapan adalah sesuatu yang membuat manusia tetap hidup. Jika tidak ada harapan, maka manusia akan putus asa dan mati. Harapan juga membuat hidup manusia menjadi dinamis. Memang, manusia hanya hidup pada saat ini, bukan pada masa lalu dan masa depan, serta dibatasi oleh ruang. Karena batasan-batasan itu, manusia hanya bergantung pada harapan. Oleh karena ada harapan, maka manusia memiliki masa depan: bahwa hidupnya akan menjadi lebih baik, pekerjaannya akan dapat diselesaikan, panen akan lebih banyak, pangkat akan naik, dan lain sebagainya.

Tapi apakah harapan itu? Thomas Aquinas menyatakan bahwa harapan adalah keinginan akan sesuatu yang baik, yang sulit untuk diwujudkan, tetapi mungkin untuk diwujudkan, "a desire of a good which is hard but not impossible to obtain." Dalam Bahasa Latin 
berbunyi: "desiderium boni possibilis ardui." Dan manusia dapat mengharap apa saja: hidup sehat, sukses dalam bisnis, dalam belajar, dalam olahraga, dan lainnya. Seorang penjudi dapat juga berharap agar menang dalam berjudi dan mengalahkan bandar judi. Seorang pencuri dapat berharap agar berhasil mencuri dan berharap agar tuan rumah tertidur saat dia mencuri. Seorang pembunuh juga berharap agar ia berhasil membunuh musuhnya. Kunci pokok sebuah harapan adalah bahwa ia mungkin untuk dapat diwujudkan meskipun sulit; dan tidak ada jaminan bahwa harapan akan terwujud.

Bagaimana sebuah harapan dapat disebut "keutamaan" (virtue) apabila harapan-harapan itu diarahkan pada hal-hal yang buruk? Thomas Aquinas menyatakan bahwa "harapan hanya diarahkan pada sesuatu yang secara moral baik dan dicintai." Keutamaan adalah suatu kebiasaan yang memungkinkan manusia untuk terus didorong melakukan tindakan-tindakan yang baik secara moral. Keutamaan adalah kecenderungan yang tetap untuk melakukan tindakan yang baik.' Maka, menurut Thomas Aquinas, harapan hanya terarah pada sesuatu yang baik, bukan diarahkan pada sesuatu yang secara moral buruk. Keutamaan adalah kualitas moral seseorang, keunggulan yang dimiliki seseorang karena ia memiliki pengetahuan dan kebijaksanaan, mencintai nilai-nilai moral, dan terus berjuang untuk melakukan tindakan-tindakan yang baik, yang selaras dengan nilai-nilai moral. Maka dari itu, melakukan tindakan yang baik menjadi kebiasaan seseorang yang memiliki keutamaan.

Keutamaan dapat dikelompokkan menjadi dua, yakni keutamaan moral dan keutamaan teologal. Keutamaan moral adalah keutamaan yang diarahkan pada realitas hidup manusia, sedangkan keutamaan teologal diarahkan pada segala sesuatu yang dikaitkan dengan Tuhan. Aristoteles menyebutkan empat keutamaan moral yang pokok, yaitu kebijaksanaan (prudence), keadilan (justice), keberanian (fortitude) dan keugahariaan/keserhanaan (temperance).

\footnotetext{
7 Summa Theologiae IIa-IIae. Q. 17 sebagaimana Karl H. Peschke, Christian Ethics. Moral Theology in the Light of Vatican II. Vol. II. (Manila: Divine World Publications, 1994), 65.

${ }^{8}$ Karl H. Peschke, Christian Ethics, Vol. II, 66.

${ }^{9}$ Karl H. Peschke, Christian Ethics. Vol. I, 343.
} 
Keutamaan teologal ada tiga, yaitu iman, harapan, dan kasih yang diambil dari surat Paulus kepada umat di Korintus (1 Korintus 13:13).

Dalam pandangan Kristen, berpengharapan merupakan keutamaan teologal di samping iman dan kasih. "Harapan adalah keutamaan teologis yang mendorong manusia untuk mengarah ke Kerajaan Surga dan kehidupan kekal sebagai kebahagiaan sejati, dan menyandarkan diri bukan pada kekuatan sendiri tetapi pada janji keselamatan Kristus, dan pada bantuan rahmat Roh Kudus."10 Tindakan umat Kristen terus menerus digerakkan oleh pengharapan yang diletakkan Tuhan di dalam hati setiap orang. Pengharapan itu menjauhkan manusia dari ketakutan, dan menjaga manusia untuk mencapai kebahagiaan abadi. ${ }^{11}$ Pengharapan umat Kristen itu memenuhi pengharapan Umat Pilihan Tuhan, pengharapan Abraham, dan pengharapan yang disabdakan Kristus dalam Sabda Bahagia. Pengharapan adalah senjata yang melindungi manusia untuk berjuang menuju keselamatan. Pengharapan diungkapkan dan diteguhkan di dalam doa, khususnya doa yang diajarkan Tuhan. ${ }^{12}$ Berkaitan dengan itu, penelitian ini mendapat pijakan kuat dari Teologi Harapan yang dipopulerkan oleh Moltman ${ }^{13}$ dan Teologi Proses dari Whitehead. ${ }^{14}$

Harapan adalah keutamaan adikodrati. Itu berarti bahwa sasaran objektif dari harapan adalah kepenuhan karya keselamatan Tuhan, dan sarana untuk menggapai objek tersebut membutuhkan bantuan rahmat Tuhan. Kepenuhan karya keselamatan Tuhan terjadi pada hari akhir atau hari kiamat ketika manusia bersatu

10 Cathecism of the Catholic Church Artikel 7, Nomor 1817 (diakses di http://ccc.usccb.org/flipbooks/catechism/files/assets/basic-html/page447.html).

11 Cathecism of the Catholic Church Artikel 7, Nomor 1818 (diakses di http://ccc.usccb.org/flipbooks/catechism/files/assets/basic-html/page447.html).

12 Cathecism of the Catholic Church Artikel 7, Nomor 1819,1820 (diakses di http://ccc.usccb.org/flipbooks/catechism/files/assets/basic-html/page448.html).

13 Jurgen Moltmann, Theology of Hope: On the Ground and the Implications of a Christian Eschatology (New York: Harper and Row, 1967).

${ }^{14}$ A. Sudiarja, "Musibah dan Bencana: Perspektif Teologi," (Yogyakarta: Bahan Kursus Teologi, Universitas Sanata Dharma Yogyakarta, 2007). 
dengan Tuhan. Maka objek tertinggi dari harapan adalah Tuhan sendiri. Dalam Bahasa yang lebih inklusif, objek harapan dirumuskan demikian:" the consummation of the messianic reign, the completion of creation in accordance with God's design, the perfection of all things in Christ as the head of the universe, and integral salvation." 15

Meskipun demikian, sasaran konkret harapan bukan hanya terarah pada keselamatan abadi, kebahagiaan abadi, dan keselamatan di akhir zaman nanti, yang dipisahkan dari kenyataan duniawi saat ini. Sasaran harapan tetaplah bertumpu pada kenyataan hidup saat ini. Kerajaan Tuhan sudah datang dan terus akan mewujud dalam kehidupan bangsa manusia. Kedamaian, keadilan, dan tata-hidup yang baik di dunia ini adalah harapanharapan yang nyata saat ini. Harapan-harapan yang nyata di dunia ini adalah antisipasi dari harapan tertinggi, yaitu kepenuhan karya keselamatan Tuhan di akhir zaman. Dengan kata lain: "although the final object of hope is the fulness of God's glory and the universal salvation, all that contributes to the realization of this universal, ultimate goal, here and now in man's earthly existence, is equally and with full right of the confidence of hope."16

Ada dua faktor yang mendorong manusia untuk terus berharap. Pertama, kepercayaan bahwa Tuhan memiliki kekuatan yang mahabesar yang selalu bersedia menolong umat-Nya. Kepercayaan ini didukung oleh bukti-bukti bahwa dalam sejarah manusia Tuhan selalu menepati janji-Nya untuk selalu menjaga umat manusia. Dalam iman Kristen, bukti paling nyata adalah Tuhan yang mewahyukan diri di dalam diri Yesus Kristus yang sudi hidup di dunia. Kedua, Tuhan selalu memberikan rahmat kasihNya di dalam sakramen-sakramen dan doa-doa yang ditujukan kepada-Nya melalui Bunda Maria dan para santo dan Gereja-Nya.

Dalam ajaran Islam, berharap juga merupakan keutamaan. Fajar Bagus Permana dalam tulisannya yang berjudul "Harapan dan Keputusasaan dalam Alquran" menunjukkan beberapa ayat

\footnotetext{
${ }^{15}$ Karl H. Peschke, Christian Ethics, Vol. II, 71.

${ }^{16}$ Ibid., 72.
} 
Alquran yang mengajarkan tentang harapan. ${ }^{17}$ Manusia harus selalu berharap kepada Allah, karena Allah sumber pengharapan. Di dalam situasi yang paling sulit sekalipun, Allah tetap akan memberikan pertolongan. Bahkan bila dalam kehidupan ini tidak ditemukan hal-hal positif, nanti di akhirat akan ditemukan. Di sini hanya dikutipkan beberapa saja: "Dan janganlah kamu membunuh dirimu. Sungguh, Allah Maha Penyayang kepadamu" (Q.S. 4:29); "Sesungguhnya yang berputus asa dari rahmat Allah, hanyalah orang-orang yang kafir" (Q.S. 12:87); "Ingatlah, sesungguhnya pertolongan Allah itu dekat" (Q.S. 2: 214).

Allah adalah sumber harapan. Dalam situasi sesulit apapun, manusia harus mengandalkan harapan kepada Allah. Bahkan bila di dalam kehidupan ini kesulitan tersebut seolah tidak dapat diatasi, masih ada harapan di akhirat nanti. Masih terdapat kebahagiaan. "Jadi, sesungguhnya, dengan setiap kesulitan, ada kelegaan: 'Maka sesungguhnya beserta kesulitan ada kemudahan. Maka apabila engkau telah selesai (dari sesuatu urusan), tetaplah bekerja keras (untuk urusan yang lain)"' (Q.S. 94: 5-7). Di dalam ajaran Islam, orang yang memiliki harapan harus melakukan tiga hal: ikhtiar, doa, dan tawakal. ${ }^{18}$

Sebagaimana dinyatakan di atas, harapan adalah sumber kehidupan manusia. Dengan terus berharap, maka manusia akan tetap hidup meskipun berada di tengah tantangan dan penderitaan. Penderitaan bukanlah akhir dari kehidupan karena masih ada harapan yang dapat membebaskan dari penderitaan itu. Dalam arti ini, harapan adalah pendorong agar manusia membangun dunia ini karena manusia dipanggil Tuhan untuk ambil bagian di dalam karya penciptaan-Nya.

17 Fajar Bagus Permana, "Harapan dan Keputusasaan dalam Al-Quran" https://www.kompasiana.com/fajar33514/5c089386bde5750a21507ce3/harap an-dan-keputusasaan-dalam-al-qur-an? (diakses 5 September 2019).

18 "Pandangan Islam mengenai Harapan" diambil dari http://www.himmaba.com/2013/04/pandangan-islam-mengenai-harapan.html, (diakses 5 September 2019). 


\section{Dimensi-Dimensi Harapan}

Meski harapan membuat manusia dapat hidup, dan hidup menjadi dinamis karena selalu terbuka akan adanya harapan untuk sesuatu yang baik, tetapi harapan juga bisa membuat manusia menjadi kecewa dan frustrasi karena ia belum tentu dapat diwujudkan. Ini dapat dimengerti, karena sasaran dari harapan berada di luar kendali manusia. Manusia tidak dapat memastikan bahwa harapannya akan dapat diwujudkan.

Berkaitan dengan hal itu, Patrick Shade dalam bukunya, Habits of Hope, membedakan antara harapan buta (blind hope) dan harapan praktis (sensible atau practical hope). ${ }^{19}$ Harapan buta tidak berdasar pada kondisi yang nyata atau real sehingga tidak ada komitmen untuk mewujudkan harapan itu. Sementara harapan praktis berdasar pada kondisi yang nyata sehingga ada komitmen dari pelaku untuk mewujudkannya. Patrick Shade mengusulkan teori pragmatis tentang harapan, dimaksudkan untuk menjembatani dua kutub harapan tersebut. Dari satu sisi, harapan harus berdasar pada kenyataan yang sesungguhnya sehingga harapan itu dapat diwujudkan dan tidak buta. Di sisi lain, harapan itu tidak boleh membatasi manusia sehingga tidak membuka diri akan adanya masa depan. Karena jika demikian, harapan tersebut kehilangan ciri dinamisnya.

Menurut Patrick Shade, teori pragmatis akan lebih memberdayakan praktikalitas harapan. Artinya, harapan itu bersifat praktis dan ada dampak konkretnya. Shade menolak teori-teori tradisional, termasuk teologi, yang mendasarkan harapan pada kekuatan Ilahi yang absolut. Bila mengikuti teori-teori tradisional, termasuk teologi, maka manusia kehilangan perannya dalam berharap. Sebaliknya, Shade mengusulkan agar mendasarkan diri pada akal budi atau intelektualitas manusia di dalam mengejar harapan, mengeksplorasi ketekunan dan kegigihan, dan meyakini bahwa harapan itu sendiri bersifat produktif dan berdayaguna di dalam menghadapi tantangan-tantangan serta memperkaya kehidupan. Demikianlah, harapan itu tidak kosong dan sia-sia.

Shade melihat harapan dalam tiga dimensi, yaitu harapan partikular (particular hopes), kebiasaan-kebiasaan berharap (babits of

19 Patrick Shade, Habits of Hope: A Pragmatic Theory (Nashville: Vanderbilt University Press, 2001), 5-6. 
bope) dan sikap penuh harapan (hopefulness). Tiga dimensi ini hanya dapat dipisahkan secara abstrak. Pada kenyataannya, tiga dimensi harapan tersebut menjadi satu. Pertama, harapan partikular (particular hopes) yaitu harapan yang diarahkan pada sasaran-sasran konkret. Setiap kali berharap, seseorang pasti mengarahkan pada sasaran-sasaran yang jelas. Misalnya: saya berharap dapat sembuh dari sakit, saya berharap dapat berhasil di dalam ujian, saya berharap dapat berhasil dalam bisnis, dan harapan lainnya. Harapan-harapan partikular ini terdapat di antara mimpi dan rencana. Sebuah mimpi tidak memiliki sasaran yang jelas; sebuah rencana memiliki sasaran yang sangat jelas. Sebuah harapan memiliki sasaran yang tidak begitu jelas. Maka letaknya di antara mimpi dan rencana.

Jika seseorang bermimpi untuk menjadi kontraktor, maka sasaran mimpinya tidaklah jelas apakah akan terwujud. Bila seseorang merencanakan untuk menjadi kontraktor, sasarannya sangatlah jelas, sehingga ia membuat langkah-langkah untuk melaksanakan rencana itu. Jika seseorang berharap untuk menjadi kontraktor, sasarannya lebih jelas dari pada mimpi di atas. Sasaran itu akan terwujud apabila ia memiliki komitmen yang kuat untuk mewujudkannya. Harapan partikular harus disertai dengan komitmen untuk mewujudkannya.

Dimensi kedua adalah kebiasaan-kebiasaan berharap (babits of hope), yaitu kemampuan-kemampuan dasar yang dimiliki seseorang yang berharap dan membantu orang itu untuk melakukan komitmen-komitmen demi terwujudnya sasaran-sasaran harapan partikular yang kurang jelas tadi. Ada tiga kebiasaan yang mesti dimiliki orang yang berharap, yaitu kegigihan (persistence), cerdik dan penuh akal/kreatif (resourcefulness), dan keberanian (courage). Tiga kebiasaan inilah yang menyebabkan orang memiliki komitmen untuk mewujudkan harapan-harapan partikular. Begitu pula, tiga kebiasaan itu membuat orang selalu mengembangkan sikap penuh harapan (bopefulness).

Dimensi ketiga yaitu sikap penuh harapan (hopefulness), yaitu sikap seseorang yang terus menerus berharap. Berharap merupakan keutamaan orang tersebut. Sikap ini sangat dekat dengan sikap optimis. Sikap ini mendorong orang untuk terus menerus berharap dan tidak pernah putus asa. Sikap ini tumbuh dan berkembang 
karena seseorang memiliki habits of hope tadi, yaitu kegigihan (persistence), cerdik dan penuh akal/kreatif (resourcefulness), dan keberanian (courage).

Dengan teorinya ini, Patrick Shade mendorong agar orang tidak terjebak pada harapan-harapan palsu atau buta. Harapan harus terus ditumbuhkan oleh kebiasaan-kebiasaan yang juga harus dikembangkan. Kebiasaan-kebiasaan berharap itu tumbuh dan dikembangkan dalam komunitas. Maka, sangatlah penting mengadakan kegiatan individual maupun kelompok yang dapat mengembangkan kegigihan, cerdik dan penuh akal (kreatif), dan keberanian. Dengan begitulah sikap penuh harapan itu akan terbentuk. Bagi masyarakat yang kerap terkena bencana seperti Indonesia, sikap penuh harap, optimis, tidak mudah putus asa ini sangatlah penting.

\section{Ungkapan, Iman, dan Kearifan Lokal}

Di dalam wawancara, FGD, dan keterlibatan langsung dalam kehidupan masyarakat Dusun Caben, peneliti mengumpulkan ungkapan, pernyataan, dan kearifan lokal dari responden yang menunjukkan sikap iman dan kepasrahan mereka. Ungkapan, pernyataan, dan kearifan lokal tersebut akan dipaparkan di sini sebagai penemuan yang akan dibahas pada bagian berikut.

(1) Tuhan yang berkehendak semua terjadi, maka saya percaya pasti Tuhan akan memulihkannya. Bagi saya hidup itu sementara, dan masih harus melanjutkan kehidupan dan demi anak-anak, maka saya tetap berupaya untuk bangkit. Iman dan sikap gotong royong menjadi faktor yang paling kuat untuk bertahan hidup dan melanjutkan kehidupan mereka.

(2) Bagi saya, iman dan tetangga menjadi faktor yang paling kuat dalam menata kehidupan.

(3) Prinsip untuk melayani menguatkan panggilan saya untuk bisa tetap berharap dan minta pertolongan dari Tuhan supaya masyarakat korban gempa segera mendapatkan pemulihan jiwa dan raga.

(4) Sejak gempa, saya menjadi sadar tentang pentingnya iman dan prinsip gotong royong. Sejak itu pula, saya mulai rajin berdoa dan bergotong royong. 
(5) Bagi saya, hidup itu milik Tuhan, maka kalau mau diambil dengan cara apapun, saya berserah kepada kehendak-Nya. Ketidakjujuran dan keserakahan beberapa orang yang selalu minta bantuan padahal mereka sudah menerima bantuan tetapi bilang belum menerima menjadi penghambat bagi saya untuk terus berpengharapan.

(6) Yang mendorong saya giat membantu tetangga adalah panggilan hati untuk memberi kasih dan pelayanan. Yang menarik bagi saya adalah saya ditantang untuk berani mengumpulkan jenasah di suatu tempat untuk segera dimakamkan.

(7) Dalam kondisi seperti ini saya tetap optimis dan memiliki harapan bahwa pasti Tuhan akan menolong.

(8) Ketika ada isu tsunami, saya justru mengajak tetangga untuk tidak pergi dan berdiam di sekitar rumah. Saya berpikir tidak mungkin ada tsunami. Saya mengajak istri pasrah kepada Allah karena saya percaya "semua kejadian ini yang membuat adalah Yang Kuasa".

(9) Saya tetap punya harapan untuk melanjutkan hidup, karena semua peristiwa Tuhan yang membuat dan banyak teman yang juga jadi korban gempa. Iman dan solidaritas antar tetanggalah yang membuat saya tidak mudah putus asa dan patah semangat.

(10) Urip mung sakdermo ndherek. Gusti lan nglampahi gesang kanthi sumarah (Hidup hanyalah sekedar ikut Tuhan dan menjalani hidup ini dengan berpasrah).

(11) Faktor yang membuat saya sekeluarga punya harapan hidup adalah "manusia adalah milik Tuhan." Tuhan bisa berbuat apa saja sesuai kehendak-Nya. Oleh karena itu bersikap pasrah pada kehendak-Nya saja dan tekun berdoa, supaya Tuhan menolong kesulitan dan penderitaanNya. Dengan bergotong royong, bahumembahu bersama dengan tetanggga yang senasib dan seperjuangan, akhirnya bisa membangkitkan semangat untuk hidup lebih baik.

(12) Saya dan keluarga besar tetap punya harapan untuk bisa bangkit, karena hidup milik Tuhan dan manusia tetap harus melanjutkan kehidupan dalam suka duka. Saya harus tetap memiliki motivasi untuk hidup dan pasrah pada 
kehendak-Nya karena saya yakin kehendak-Nya sungguh amat baik. Sikap iman dan optimisme yang tinggi merupakan dorongan yang paling kuat berpengaruh dalam hidup saya saat itu.

(13) Saya tetap memilik harapan karena banyak yang menjadi korban gempa, yang mengalami nasib sama. Pengalaman gempa justru menumbuhkan semangat solidaritas yang tinggi.

(14) Faktor yang menyebabkan punya harapan adalah semangat gotong royong, solidaritas dan kepasrahannya kepada Tuhan yang punya hidup.

(15) Sikap saling peduli itulah yang membuat ia masih tetap memiliki harapan meski dukanya tidak bisa digambarkan. Sejak itu semakin percaya kepada Tuhan dan tekun melakukan doa pribadi dan doa di lingkungan, serta gotong royong tidak pernah ditinggalkannya. Semangat solidaritas dan iman yang paling kuat berpengaruh untuk bangkit dari penderitaannya.

(16) Yang mengerikan adalah ketika pergi karena isu tsunami, melihat ada tetangga yang diikat di pohon karena tidak mungkin diajak pergi, dengan harapan kalau kena air biar tetap di pohon. Bagi saya hidup hanya mampir minum, maka pasrah kepada kehendak-Nya, supaya diatur olehNya.

(17) Maka saya pun pasrah pada kuasa kasih Tuhan, karena Tuhan yang menjadi pemilik kehidupan ini. Selalu berpegang pada "Yesus adalah jalan, kebenaran dan hidup" dan Yesus adalah andalanku maka saya tidak takut, meski takut. Iman dan sistem gotong royong yang menjadi daya penggerak paling berpengaruh dalam membangkitkan semangat hidupnya.

(18) Memang ada bantuan yang tidak sampai ke tujuan tetapi dinikmati sendiri oleh oknum.

(19) Gusti mboten badhe nyobi. Gusti kepengin sadaya sami sugeng (Tuhan tidak akan mencobai. Tuhan ingin semua orang hidup). Gempa malah dadi berkah; semula tak punya rumah, sekarang punya.

(20) Karena pertolongan Yang Kuasa, saya masih selamat. Kalau dipikir tidak masuk akal. 
(21) Tiap malam stres. Tiap malam hanya dengan istri, saling mengisi, saya menyadarkan, meneguhkan. Pokoknya jangan mengeluh. Jangan menyesali keadaan. Sepakat dengan istri untuk bangkit lagi, usaha, warungan kecil. Bisa bertahan sampai sekarang. Tetap semangat. Ujian dari Tuhan bermacam-macam; menerima adanya; selalu bersyukur, selalu berdoa.

(22) Waktu isu tsunami saya tidak lari. Saya berkata, "sing wedi mati mlayua" (siapa yang takut mati silahkan lari). Saya ngurusi yang sakit dan meninggal.

(23) Semua sudah diatur yang Kuasa. Gusti Allah nyoba umate, sing kuwat. Urip karo jodho sing nemtokke sing Kuwasa (Allah memberikan cobaan umat yang kuat. Hidup dan jodoh ditentukan oleh Yang Kuasa).

Dari 23 ungkapan atau pernyataan yang dikutip di atas, 20 ungkapan atau pernyataan menyatakan bahwa sikap pasrah kepada Tuhan merupakan landasan bagi para penyintas untuk segera bangkit dari keterpurukan. Hanyalah tiga ungkapan atau pernyataan yang tidak menyatakan hal tersebut. Pelbagai macam variasi ungkapan atau pernyataan pasrah kepada Tuhan tersebut menunjukkan dimensi-dimensi iman para penyintas.

Pertama, Tuhan dihayati sebagai asal dan tujuan dari segala-galanya. Ini tampak pada ungkapan-ungkapan berikut: "Tuhan yang berkehendak semua terjadi, maka saya percaya pasti Tuhan akan memulihkannya"; "semua kejadian ini yang membuat adalah Yang Kuasa"; dan "semua peristiwa Tuhan yang membuat."

Kedua, Tuhan dihayati sebagai penolong. Ini tampak dalam ungkapan-ungkapan berikut: "saya tetap optimis dan memiliki harapan bahwa pasti Tuhan akan menolong"; "Karena pertolongan Yang Kuasa, saya masih selamat. Kalau dipikir tidak masuk akal."

Ketiga, Tuhan dihayati sebagai andalan dalam segala hal. Manusia hanya bisa menyandarkan seluruh hidupnya pada Tuhan. Hal ini tampak pada ungkapan-ungkapan berikut: "Hidup hanyalah sekedar ikut Tuhan dan menjalani hidup ini dengan berpasrah"; "manusia adalah milik Tuhan"; "Tuhan bisa berbuat apa saja sesuai kehendak-Nya"; "Tuhan yang menjadi pemilik kehidupan ini"; "Tuhan tidak akan mencobai. Tuhan ingin semua orang hidup"; dan "Hidup dan jodoh ditentukan oleh Yang Kuasa." 
Sikap dan ungkapan para penyintas di atas selaras dengan pandangan teologi Kristen, Islam, dan agama-agama pada umumnya. Iman mengandung tiga unsur hakiki, yaitu (1) sebagai penyerahan diri secara total kepada Tuhan, (2) kepercayaan yang penuh seharusnya menuntun manusia kepada kesetiaan, kesetiaan akan Allah, dan (3) iman sebagai "peran ketaatan". ${ }^{20}$

Iman dalam arti kepasrahan yang total itulah yang merupakan landasan bagi umat manusia untuk memiliki pengharapan. Dalam surat kepada umat Ibrani dinyatakan, "Iman adalah dasar dari segala sesuatu yang kita harapkan dan bukti dari segala sesuatu yang tidak kita lihat" (Ibrani 11:1). Menurut Thomas Aquinas, sebagaimana dikutip oleh Chang, ${ }^{21}$ kutipan Ibrani 11:1 ini menekankan bahwa "iman adalah substansi atau landasan pengharapan, atau landasan seluruh karya pembenaran; sekaligus menjadi bukti dari kepastian yang tidak kita lihat."

Hal itulah yang menjadi pengalaman penduduk Dusun Caben yang mengalami bencana gempa bumi pada Mei 2006. Pasrah secara total kepada Tuhan menjadi landasan untuk memiliki pengharapan. Memang, secara teologis pengharapan yang dimaksud adalah pengharapan akan Kerajaan Allah, keselamatan di akhir zaman, yang abstrak. Namun, bukan berarti pengharapan akan keselamatan abadi tersebut sama sekali terlepas dari pengharapan-pengharapan yang konkret atau temporer. ${ }^{22}$

Pengharapan yang konkret dari para penyintas gempa di Bantul mengalir dari iman mereka pada Tuhan, Sang Sumber Keselamatan. Para penyintas punya pengharapan yang kuat bahwa mereka akan segera bangkit dari keterpurukan karena kepasrahan mereka kepada Tuhan. Memang, yang mereka harapkan adalah keselamatan yang sungguh konkret, misalnya: mendapat kiriman nasi bungkus, mendapat bantuan tenda, terpal, atau mendapat bantuan dana untuk membangun rumah. Pengharapan yang konkret tersebut berlandaskan pada iman mereka akan Tuhan yang menjadi asal dan tujuan, penolong, serta penyelenggara kehidupan.

\footnotetext{
${ }^{20}$ Williamm Chang, Moral Spesial (Yogyakarta: Penerbit Kanisius, 2015), 25-26.

${ }^{21}$ Ibid., 27.

${ }^{22}$ Karl H. Peschke, Christian Ethics, 71.
} 
Ini selaras dengan penelitian Bernard Adeney Risakota tentang pengaruh agama di dalam memberi makna atas penderitaan. ${ }^{23}$

Patrick Shade yang menjadi rujukan penelitian ini tidak menerangkan bagaimana particular hopes (harapan-harapan konkret) itu dapat muncul. Dia menolak konsep-konsep tradisional, termasuk teologi, yang mendasarkan pengharapan pada kekuatan absolut, yaitu Tuhan. ${ }^{24}$ Dengan teori pragmatik, dia menyatakan bahwa manusia harus menggali dan mengembangkan kebiasaan berharap yang telah dimilikinya, melalui pelbagai aktivitas hingga akhirnya terbentuklah sikap penuh harap (bopefulness), bukan mendasarkan diri pada kepasrahan kepada Tuhan.

Pengalaman masyarakat dusun Caben membuktikan bahwa harapan-harapan konkret mereka tumbuh oleh karena iman mereka kepada Tuhan. Masyarakat Dusun Caben pasrah dan beriman kepada Tuhan sebagaimana tampak dari ungkapanungkapan di atas. Dari kepasrahan dan iman tersebut tumbuhlah pengharapan. Berdasarkan pengalaman ini, tidak mungkinlah harapan-harapan itu digali hanya dengan intelektualitas saja. Harapan-harapan masyarakat Dusun Caben untuk dapat bangkit dari keterpurukan muncul dan terus berkembang oleh karena sikap pasrah dan beriman kepada Tuhan. Dengan demikian, teori pragmatik dari Patrick Shade tidak selaras dengan pengalaman masyarakat Dusun Caben. Mungkin saja, teori pragmatik dari Patrick Shade dapat diterapkan dalam masyarakat sekuler dan tidak dapat diterapkan dalam masyarakat religius seperti masyarakat Dusun Caben dan masyarakat Indonesia pada umumnya.

\section{Tuhan Hadir dalam Kasih dan Solidaritas}

Pernyataan para penyintas dalam wawancara dan diskusi menegaskan bahwa kepasrahan dan pengharapan mereka kepada Tuhan tumbuh kuat pada saat mereka merasakan banyaknya bantuan yang mengalir. Mereka merasakan banyaknya orang dari pelbagai tempat, tanpa memandang sekat apapun, yang dengan murah hati memberikan bantuan kepada mereka. Bantuan berupa

23 Bernard Adeney Risakota, "Is there a Meaning in Natural Disasters? Constructions of Culture, Religion and Science," Exchange: Journal of Missiological and Ecumenical Research (Netherlands: October, 2008).

24 Patrick Shade, Habits of Hope, 10. 
makanan, barang-barang yang langsung digunakan, uang, dan tenaga merupakan wujud kasih dan solidaritas antar sesama.

Ternyata kasih dan solidaritas tersebut menyadarkan para penyintas akan kasih Tuhan; Tuhan hadir di dalam kasih dan solidaritas sesama manusia. Allah adalah kasih itu sendiri. Para penyintas menyatakan bahwa bantuan-bantuan tersebut yang meneguhkan iman dan pengharapan mereka. Ada yang menyatakan, "Sejak gempa, saya menjadi sadar tentang pentingnya iman dan prinsip gotong royong. Sejak itu pula, saya mulai rajin berdoa dan bergotong royong." Pernyataan lain berbunyi, "Dalam kondisi seperti ini saya tetap optimis dan memiliki harapan bahwa pasti Tuhan akan menolong."

Iman kepada Tuhan tidaklah dihayati dalam kehampaan yang abstrak. Iman kepada Tuhan hidup dan terus tumbuh di dalam kasih manusia. Hal itu selaras dengan pernyataan Paulus bahwa kasih adalah keutamaan yang paling tinggi. "Demikianlah tinggal ketiga hal ini, yaitu iman, pengharapan dan kasih, dan yang paling besar di antaranya ialah kasih" (1 Korintus 13:13). Kasih itu menyatukan dan menyempurnakan segala-galanya. "Dan di atas semuanya itu: kenakanlah kasih, sebagai pengikat yang mempersatukan dan menyempurnakan" (Kolose 3:14). Hal ini selaras dengan pendapat Katiestockdale dan Michaelmilona dalam artikelnya yang berjudul "A Perceptual Theory of Hope" bahwa harapan itu muncul dari pengalaman-pengalaman yang hadir pada seseorang (presentational experience). ${ }^{25}$

Kasih dan solidarias mendorong para penyintas untuk semakin peduli pada sesama mereka. Dengan bergotong royong, bahu membahu bersama dengan tetanggga yang senasib dan seperjuangan akhirnya bisa membangkitkan semangat untuk hidup lebih baik. Dua orang Ketua RT di dusun Caben menyatakan bahwa mereka mengutamakan keselamatan warga mereka terlebih dahulu dari pada kepentingan pribadi. Mereka rela untuk mengurus pemakaman tetangga mereka yang mati, mengurus makanan dan tenda untuk warga mereka, meskipun rumah dan keluarga mereka

25 Katiestockdale dan Michaelmilona, "A Perceptual Theory of Hope" dalam Ergo, Vol. 5, No. 8, (2018). Diakses dari http://dx.doi.org/10.3998/ergo.12405314.0005.008. 
sendiri belum terurus. Barulah di hari terakhir, rumah Pak RT dibereskan secara gotong royong oleh warga.

Kasih dan solidaritas menumbuhkan pengharapan dan iman. Pengharapan, sebagaimana dinyatakan di atas, berlandaskan iman kepada Tuhan. Dua orang warga mengalami nasib yang serupa, yaitu ditinggal mati oleh anak-anak kesayangan mereka. Pak Wardi ditinggal mati anak perempuannya, sedang pak Warjiyono ditinggal mati anak laki-lakinya. Mereka begitu yakin bahwa Tuhan akan memberikan ganti dari anak-anak mereka. Memang benar, beberapa tahun kemudian Pak Wardi dianugerahi anak laki-laki, sedangkan Pak Warjiyono mendapatkan anak perempuan pada saat usia istrinya sudah 40-an. Bahkan Pak Warjiyono sudah menyiapkan biaya operasi cesar untuk istrinya dan obat-obatan termahal bagi penyembuhan istrinya kelak bila sudah operasi. Namun, berkat kemurahan Tuhan, istrinya dapat melahirkan dengan normal dan obat-obatan pun diperoleh tanpa harus membayar. Pak Warjiyono ini kehilangan rumah yang baru selesai dibangun dengan uang pinjaman sebesar 40 juta rupiah. Pinjaman itu baru diangsur dua kali. Selanjutnya, dia harus menyelesaikan pembayaran hutang tersebut, meskipun rumahnya sudah hancur.

Sebagaimana ditulis di atas, Patrick Shade tidak menyebutkan bagaimana particular hopes (harapan yang konkret) itu dapat tumbuh. Dia mengandaikan bahwa harapan-harapan konkret itu akan dapat ditumbuhkan dengan menggali intelektualitas manusia. Dari pengalaman masyarakat dusun Caben, harapanharapan konkret dapat tumbuh karena adanya kasih dan solidaritas dari sesamanya. Harapan-harapan konkret tidak akan tumbuh begitu saja tanpa adanya pengalaman konkret. Kebiasaan berharap dan sikap penuh harap juga akan tumbuh oleh karena pengalaman diberi bantuan, kasih, dan solidaritas dari sesamanya.

\section{Membangun Masyarakat Berpengharapan}

Di dalam wawancara dan diskusi, tidak banyak diungkapkan tentang adanya faktor-faktor penghambat bagi masyarakat untuk terus berharap. Tetapi sewaktu disinggung adanya kasus-kasus penjarahan dan bantuan-bantuan yang tidak sampai ke alamat yang dituju, para penyintas mulai menceritakan bahwa adanya ketidakjujuran dan keserakahan dari sebagian kecil warga dapat menjadi penghambat tumbuhnya pengharapan. Memang 
ada kasus-kasus tentang bantuan yang tidak sampai ke alamat. Ada pula sebagian kecil warga yang sebenarnya sudah menerima bantuan tetapi mengatakan belum menerima bantuan. Begitu pula ada pihak-pihak tertentu yang mengambil keuntungan di tengah penderitaan orang lain, misalnya: penjarahan dan pencurian. Ketidakjujuran dan keserakahan ini membuat para penyintas menjadi pesimis dan agak putus asa. Untunglah, kasus-kasus semacam itu tidaklah banyak. Kasih dan solidaritas lebih besar dari pada kasus-kasus negatif tersebut.

Dapat dipahami apabila ketidakjujuran dan keserakahan menjadi penghambat dari tumbuh berkembangnya pengharapan, karena ketidakjujuran dan keserakahan merupakan lawan dari kasih dan solidaritas. Kasih dan solidaritas menumbuhkan iman dan pengharapan, maka lawan mereka, yaitu ketidakjujuran dan keserakahan akan melumpuhkan pengharapan. ${ }^{26}$ Keserakahan para sesama penyintas menyebabkan putus asa bagi para penyintas lainnya. Apalagi adanya penjarahan dari orang-orang yang berniat jahat, menggunakan penderitaan orang lain untuk mendapatkan keuntungan sendiri. Sikap-sikap negatif ini akan menimbulkan keputusasaan dan menjadi penghambat tumbuhnya pengharapan.

Penelitian ini menemukan bahwa kasih dan solidaritas yang tumbuh dan berkembang di tengah pengalaman bencana berkaitan erat dengan (dan tidak dapat dipisahkan dari) keutamaan harapan dan iman kepada Tuhan. Kasih dan solidaritas bukanlah keutamaan yang berdiri sendiri. Kasih dan solidaritas dapat menumbuhkan pengharapan. Pengharapan para penyintas untuk segera bangkit dari keterpurukan tumbuh oleh karena pengalaman mendapat bantuan dari pelbagai pihak. Bantuan dari banyak pihak itu disadari oleh para penyintas sebagai wujud dari kasih Tuhan sendiri.

Usaha untuk membangun masyarakat berpengharapan dapat dilakukan dengan memperbanyak kegiatan pengembangan solidaritas. Kebiasaan untuk berbagi kepada tetangga dan orang yang membutuhkan sangatlah bagus untuk mengembangkan

\footnotetext{
26 Peskhe menyebutkan lawan harapan adalah praduga (presumption), putus asa (despair), dan kecil hati (faint-heartedness, resignation). Karl H. Peschke, Christian Ethics,.79-81.
} 
solidaritas ini. Bagi orang yang memberi, sikap ini akan menumbuhkan kepedulian yang bisa direfleksikan sebagai sikap iman. Bagi mereka yang diberi, pemberian ini dapat diterima dengan penuh syukur sebagai anugerah Tuhan.

Memang, kerap kali bantuan-bantuan hanya dilihat sisi yang sangat material dan bisa jadi terbatas. Seringkali para penyintas masih harus bersusah payah untuk mencukupi kebutuhan lain. Oleh karena itu, bantuan material harus dilengkapi dengan bantuan mental-spiritual, berupa penghiburan rohani agar para penyintas tidak terhenti pada bantuan material, tidak sampai pada refleksi tentang kasih Tuhan. Latihan untuk menghargai penghiburan rohani, seperti kunjungan, doa, dan ucapan penghiburan, menjadi sangat penting.

Sebagai bentuk prevensi bagi masyarakat yang rentan terkena bencana, pertemuan dan sarasehan yang dapat menumbuhkan semangat gotong royong harus kerap diselenggarakan. Harus dibuat buku modul sarasehan yang terstruktur untuk mengembangkan kepribadian masyarakat. Titik tekan dalam sarasehan adalah melatih untuk rendah hati, bersedia berbagi, dan bersedia bersyukur atas pemberian apapun. Masyarakat yang dibiasakan untuk mengadakan latihan rohani semacam ini tidak akan mudah terjebak kepada kebutuhan sesaat. Dengan demikian, apabila mereka suatu saat terkena bencana dan penderitaan, mereka akan siap secara mental untuk terus memiliki keutamaan iman, harapan, dan kasih atau solidaritas.

\section{Penutup}

Penelitian ini meneguhkan bahwa keutamaan kasih dan solidaritas sangat erat berhubungan dengan keutamaan pengharapan dan iman. Penelitian yang hanya terhenti pada kekaguman atas solidaritas manusia di tengah-tengah bencana mesti diteruskan ke penelitian tentang kaitan antara solidaritas dengan keutamaan lain. Penelitian ini juga menyarankan adanya kegiatan berupa pertemuan atau sarasehan yang dapat mempererat kasih dan solidaritas antarwarga untuk membangun masyarakat berpengharapan. Masyarakat yang berpengharapan sangatlah relevan bagi Indonesia yang penuh dengan bencana. Pertemuan atau sarasehan tersebut sebaiknya bersifat umum, tanpa 
pembedaan berdasar agama atau pengelompokan lain. Pengelompokan berdasar tingkat umur dan pendidikan bisa dilakukan hanya dengan pertimbangan kelancaran dalam berkomunikasi saja.

\section{Daftar Pustaka}

Brata, Aloysius Gunadi, et al.. "The Impact of the 2006 Yogyakarta Earthquake on Local Economic Growth." EconDisCliCha (2018). (dapat diakses di https://doi.org/10.1007/s41885018-0026-5).

Cathecism of the Catholic Church. Manila: Word and Life Publications, 1994. (bisa diakses di http://ccc.usccb.org/flipbooks/catechism/files/assets/basic $-\mathrm{html})$.

Chang, Williamm. Moral Spesial. Yogyakarta: Penerbit Kanisius, 2015.

Katiestockdale dan Michaelmilona. "A Perceptual Theory of Hope." Ergo, Vol. 5, No. 8, (2018). (dapat diakses di http://dx.doi.org/10.3998/ergo.12405314.0005.008).

Moltmann, Jurgen. Theology of Hope: On the Ground and the Implications of a Christian Eschatology. New York: Harper and Row, 1967.

Peschke, Karl H. Christian Ethics. Moral Theology in the Light of Vatican II. Manila: Divine World Publications, 1994.

Rahardjo, Albertus Kristiadji. Theology of Solidarity in Times of Disaster and Suffering. Theological Reflections Based on the Experiences of a Post-Disaster Christian Community in Kintelan, Bantul, Yogyakarta. Yogyakarta: Thesis CRCS, 2007.

Risakotta, Bernard Adeney. "Is there a Meaning in Natural Disasters? Constructions of Culture, Religion and Science." Exchange: Journal of Missiological and Ecumenical Research, (Netherlands: October 2008).

Shade, Patrick. Habits of Hope. A Pragmatic Theory. Nashville: Vanderbilt University Press, 2001.

Sudiarja, A. "Musibah dan Bencana: Perspektif Teologi." Yogyakarta: Bahan Kursus Teologi Universitas Sanata Dharma Yogyakarta, 2007.

Suliantoro, Bernadus Wibowo. Studi Tentang Orientasi Nilai Budaya Abdi Dalem Kraton Yogyakarta. Yogyakarta: Laporan Penelitian Mandiri, Universitas Atma Jaya Yogyakarta, 2001. 
Suseno, Franz Magnis. Etika Jawa Sebuah Analisa Falsafi tentang Kebijaksanaan Hidup Jawa. Jakarta: Gramedia, 1984.. 